\title{
Screening colonoscopy: should we focus more on technique and less on technology?
} Noor Mohammed ${ }^{1}$ and Venkataraman Subramanian ${ }^{1,2 *}$

Addresses: ${ }^{1}$ Department of Gastroenterology and ${ }^{2}$ Leeds Institute of Molecular Medicine St James University Hospital, Leeds Teaching Hospital NHS Trust, Leeds LS9 7TF

*Corresponding author: Venkataraman Subramanian (v.subramanian@leeds.ac.uk)

Fl000Prime Reports 2013, 5:32 (doi:10.12703/P5-32)

This is an open-access article distributed under the terms of the Creative Commons Attribution-Non Commercial License (http://creativecommons.org/licenses/by-nc/3.0/legalcode), which permits unrestricted use, distribution, and reproduction in any medium, provided the original work is properly cited. You may not use this work for commercial purposes.

The electronic version of this article is the complete one and can be found at: http://fl000.com/prime/reports/m/5/32

\begin{abstract}
Several large studies have confirmed that high quality colonoscopic surveillance can improve outcomes with substantial reduction in colorectal cancer rates. In order to improve outcomes from screening colonoscopy and help detect adenomas, the emphasis has been mainly on improvements in technology like high-resolution scopes, computerized as well as dye-based chromoendoscopy and wide-angle endoscopes. In addition to the equipment and technological innovation in the equipment used, a number of other factors like experience of the endoscopist, optimal withdrawal techniques, position changes during colonoscopy and bowel preparation can all influence adenoma detection and thereby the quality of colonoscopic surveillance. In this review we will focus on recent studies investigating these aspects of colonoscopy and their impact on adenoma or polyp detection.
\end{abstract}

\section{Introduction}

Colorectal cancer is the second leading cause of death in the US and the UK. Screening colonoscopy with resection of detected polyps has reduced the subsequent risk for developing colorectal cancer as well as the risk of colorectal-cancer-related mortality $[1,2]$. This enthusiasm in screening colonoscopy has been tempered by some studies that have shown that colonoscopy performs poorly in reducing mortality from right-sided cancers $[3,4]$. However, several large studies have confirmed that high-quality colonoscopic surveillance can improve outcomes with a substantial reduction in colorectal cancer rates $[5,6]$. This has resulted in several national societies, including the British Society of Gastroenterology (BSG) and the American Gastroenterology Association (AGA), focusing on adenoma detection rate as a performance or quality indicator in colonoscopy. In order to improve outcomes from screening colonoscopy and help detect adenomas, the emphasis of late has been focused more on technology like highresolution scopes, computerized as well as dye-based chromoendoscopy and wide-angle endoscopes rather than technique.

In addition to the equipment and technological innovation in the equipment used, a number of other factors like experience of the endoscopist, optimal withdrawal techniques, position changes during colonoscopy and bowel preparation can all influence adenoma detection and thereby the quality of colonoscopic surveillance, In this review we will focus on recent studies investigating these aspects of colonoscopy and their impact on adenoma or polyp detection.

\section{Techniques in colonoscopy}

Unarguably, the main challenge in colonoscopy is to ensure adequate mucosal visualization at both insertion and withdrawal. Optimal bowel preparation, effective use of sedation, position change and ancillary maneuvers during the procedure and improved withdrawal technique, adequate distension of the bowel throughout examination are some of the basic steps that could 
collectively improve the outcomes. The impacts of these techniques are discussed separately below.

\section{Bowel preparation}

Inadequate bowel preparation has been variably defined and can be thought of as preparation that results in an inability to visualize a polyp of $5 \mathrm{~mm}$ or larger [7]. Suboptimal mucosal visualization decreases adenoma detection. Studies suggest that up to one third of the colonoscopies performed are compromised by poor bowel preparation [8], which in most cases precludes any planned endoscopic therapy. This requires a repeat procedure or alternative investigations, thus delaying the diagnosis and wasting resources.

Two bowel cleansers are widely used, polyethylene-glycol and electrolyte lavage solution (PEG+ELS), and sodium picosulphate $(\mathrm{NaP})$ with or without PEG. PEG+ELS has very minimal fluid and electrolyte shift between the intestinal cells, and is safer for the majority of the patient groups, but patient compliance and acceptability due to its large volume (4 liter solution) is poor.

Recent studies have suggested that a split dose regimen of either PEG+ELS or NaP solutions improves bowel preparation scores for colonoscopy over standard methods where bowel preparation is taken a day prior to colonoscopy (Table 1). A meta-analysis comparing $\mathrm{NaP}$ with PEG did not show any difference between the two but PEG-based solutions performed better for clinically important outcomes like quality of preparation of the proximal colon [9]. However, a recent meta-analysis of studies comparing split versus standard colonoscopy preparation strategies showed that 4 liter split-dose PEG is better than other bowel preparation methods for colonoscopy [10]. A system side implementation of split dose preparation in a large US centre found significant improvements in adenoma detection rate compared to a historical control group prior to implementation of the split dose colonoscopy preparation [11]. Table 1 lists some of these studies and their outcomes.

\section{Procedure-related aspects}

Techniques such as changing the position of the patient to aid insertion and to improve adenoma detection rate on withdrawal are well known but perhaps not adhered to adequately by many colonoscopists. Withdrawal time and technique are widely believed to be quality indicators of colonoscopy, but have also been argued to be surrogates for other quality indicators. More recently, queue position (timing of colonoscopy in the day shift) has been considered as a cause for variation in adenoma detection among colonoscopists. Some studies have shown that as the day progresses, polyp detection rate deteriorates, presumably due to operator fatigue and time pressure, whereas some have found no difference (see table 2). This implies that perhaps the differences are operator dependent and not universal.

Heightened awareness of colonoscopists either by filming/ video-recording, presence of observer or a trainee in the room seems to have a positive impact on the colonoscopy outcomes. Additional stressors such as being behind the schedule, staff pressures, case volume, and interruption during the list may have a negative impact. These issues highlight that there are complex and dynamic "behind the scene" activities that have a bearing on standards of colonoscopy performed.

Table I. Recent studies on the role of split dose bowel preparation for colonoscopy

\begin{tabular}{llll}
\hline Author (year) ref & Study Design & Comments & Results \\
\hline Flemming JA (20I2) [27] & RCT & Split dose of NaP used & Favours Split dose regime NaP. \\
Seo EH (2012) [28] & Prospective observational study. & Split dose of PEG+ELS used & Favours Split dose regime PEG+ELS. \\
Enestvedt BK (2012) [10] & Meta-analysis & Split dose versus conventional & Split doses of PEG found superior \\
\hline
\end{tabular}

Abbreviations: PEG, polyethylene glycol; ELS, electrolyte lavage solution

Table 2. Recent studies on queue position and operator fatigue on adenoma detection

\begin{tabular}{|c|c|c|c|}
\hline Author (year) ref & Study design & Details & Results \\
\hline Lurix E (20I2) [29] & Retrospective review & $\begin{array}{l}3085 \text { procedures. ADR variation with } \\
\text { queue positions. }\end{array}$ & $\begin{array}{l}\text { ADR does not vary with queue position, } \\
\text { full day blocks or timing. }\end{array}$ \\
\hline Guruda S (20II) [30] & Retrospective review & $\begin{array}{l}4665 \text { procedures. ADR variation with } \\
\text { queue positions. }\end{array}$ & $\begin{array}{l}\text { Half day blocks increase but full day } \\
\text { blocks decrease ADR }\end{array}$ \\
\hline Lee A (20II) [3I] & Retrospective review & $\begin{array}{l}1083 \text { procedures. PDR variation with } \\
\text { queue positions. }\end{array}$ & $\begin{array}{l}4.6 \% \text { reduction in PDR with each hour } \\
\text { elapsed. }\end{array}$ \\
\hline Long M (2010) [32] & Retrospective review & $\begin{array}{l}342 \text { I procedures. ADR variation with } \\
\text { queue positions. }\end{array}$ & $\begin{array}{l}\text { ADR affected as time progresses in both } \\
\text { half and full day blocks. }\end{array}$ \\
\hline
\end{tabular}




\section{Queue position}

To look at the effect of operator fatigue on adenoma detection rate, various studies have examined the timing of the endoscopy list and work patterns, such as effect of full day versus half day blocks and more recently three three-hour shifts compared with the standard two fourhour endoscopy lists. Table 2 lists recent studies and the effects of queue position and operator fatigue.

\section{Position change, ancillary maneuvers, withdrawal time and technique}

Improved adenoma detection with position change of patients in association with adequate luminal distension during withdrawal phase of colonoscopy is a wellestablished fact $[12,13]$. Withdrawal time and its effect on adenoma detection rate, by both experienced and trainee colonoscopists, however, has been controversial. Table 3 lists some of the recent studies looking at withdrawal time and adenoma detection rate.

\section{A second pair of eyes}

Conscientious colonoscopists take extra care not to miss pathology, but, even so, an extra pair of eyes may help improve adenoma detection rate. To this end, the effect of video recording of a procedure, and a "fellow effect" (presence of trainee in the room) on adenoma detection rate has been studied. This newly recognized behavioral issue among colonoscopists is difficult to study yet important to address. Observation perhaps acts as a form of "peer review" and reduces the likelihood of "cutting corners". Table 4 lists the recent studies looking at adenoma detection rate with video recording of the procedure or the presence of a trainee.

\section{Retroflexion and retroversion}

Retroflexion in the rectal ampulla combined with making a $180^{\circ}$ rotation of the scope tip has been claimed to improve mucosal visualization and could therefore improve the detection of adenomas. Saad et al. found that in 1502 consecutive colonoscopies, rectal retroflexion was successful in 94\%, but resulted in the detection of an additional seven polyps of which six were hyperplastic and one a $4 \mathrm{~mm}$ adenoma [14]. Attempts to retrovert the colonoscope at the caecum and ascending colon has had mixed results. The technical success was only $60 \%$ using standard pediatric colonoscopies but 95\% using prototype instruments with an extra flexible tip [15]. Retroflexion in the right colon was not shown to improve adenoma detection over standard forward viewing in a study from Indiana [16].

Table 3. Recent studies on the effect of withdrawal time on adenoma detection

\begin{tabular}{|c|c|c|c|}
\hline Author (year) ref & Study design & Comments & Results \\
\hline Adler A (20I2) [33] & Retrospective review & $\begin{array}{l}\text { I2I34 Procedures. ADR variation } \\
\text { with WT. }\end{array}$ & $\begin{array}{l}\text { No correlation with } 6 \text { minutes WT and } \\
\text { ADR but instead influenced by operator } \\
\text { and instrument quality. }\end{array}$ \\
\hline Lee RH (20II) [34] & $\mathrm{RCT}$ & $\begin{array}{l}\text { I } 10 \text { video recordings reviewed for } \\
\text { withdrawal technique. WT noted. }\end{array}$ & $\begin{array}{l}\text { WT and technique differs between } \\
\text { endoscopists having varying ADR. WT } \\
\text { range 6.3-10.2 minutes. }\end{array}$ \\
\hline Gromski MA (20II) [35] & Prospective observational study & $\begin{array}{l}\text { First year trainees involved in } \\
\text { recording their WT and ADR }\end{array}$ & $\begin{array}{l}\text { WT> }>10 \text { minutes had significantly higher } \\
\text { ADR }\end{array}$ \\
\hline Overholt BF (20I0) [36] & Prospective multi-centred study & I5955 procedures reviewed for WT & $\begin{array}{l}\text { WT }>6 \text { minutes increases Polyp } \\
\text { detection. }\end{array}$ \\
\hline
\end{tabular}

Abbreviations: ADR, adenoma detection rate; WT, withdrawal time

Table 4. Studies on trainee involvement or video recording and adenoma detection

\begin{tabular}{|c|c|c|c|}
\hline Author (year) ref & Study design & Comments & Results \\
\hline Buchner AM (20II) [37] & Retrospective review & $\begin{array}{l}2430 \text { procedures. Trainees involvement } \\
\text { \& ADR noted }\end{array}$ & $\begin{array}{l}\text { Increased detection of small } \\
\text { adenomas noted with trainee present. }\end{array}$ \\
\hline Eckardt AJ (2009) [38] & Prospective study & $\begin{array}{l}387 \text { procedures. Trainee involvement } \\
\text { \& ADR noted. }\end{array}$ & $\begin{array}{l}\text { No significant difference noted in } \\
\text { ADR with or without trainee. }\end{array}$ \\
\hline Rex DK (20II) [39] & $\begin{array}{l}\text { Prospective video recording of } \\
\text { colonoscopy skills }\end{array}$ & $\begin{array}{l}7 \text { colonoscopists involved with/without } \\
\text { informing about video recording }\end{array}$ & $\begin{array}{l}\text { Mucosal visualization time and } \\
\text { technique improved with awareness } \\
\text { of video recording. }\end{array}$ \\
\hline Madhoun MF (20I2) [40] & $\begin{array}{l}\text { Video recording of all } \\
\text { colonoscopies }\end{array}$ & $\begin{array}{l}\text { All colonoscopists were aware of the video } \\
\text { recording }\end{array}$ & $\begin{array}{l}\text { No significant increase in ADR, but } \\
\text { increase in detection of hyperplastic } \\
\text { polyps noted }\end{array}$ \\
\hline
\end{tabular}




\section{Looking for polyps at insertion and withdrawal}

Traditionally, endoscopists have limited scope for systematic inspection of the mucosal surface to detect adenomas during the withdrawal phase of the procedure. A recent randomized trial looked at the effect of including the insertion phase in the adenoma detection process and found that inspection during insertion had no additional benefit on adenoma detection rate [17]. However, another European RCT found that removal of polyps smaller than $10 \mathrm{~mm}$ only on the withdrawal phase resulted in a lower adenoma detection rate compared to removal of these polyps in both insertion and withdrawal phases [18].

\section{Use of antispasmodics}

The role of using antispasmodics (mainly hyoscine N-butylbromide) has been controversial. Two recent studies have provided conflicting results on the use of antispasmodics and adenoma detection rate. An RCT from the Netherlands found no difference in both the detection of adenomas and advanced adenomas with the use of hyoscine N-butylbromide [19]. An Australian RCT, however, found that the adjusted odds of detecting an adenoma were 1.6 fold in the group receiving hyoscine N-butylbromide [20]. However, the adenoma detection rate between the groups was not significantly different.

\section{Operator experience and expertise}

A landmark study from Poland showed that endoscopists with a greater than $20 \%$ adenoma detection rate had a significantly lower rate of interval colorectal cancer [5]. More recent data from North America has confirmed that endoscopists with a higher polypectomy rate also have lower rates on interval colorectal cancer $[21,22]$. Interestingly, several studies have also shown an inverse relationship between endoscopists who classed themselves as Gastroenterologists and interval colorectal cancer rates [21-23].

A study from the UK, however, showed that operator volume and accreditation as bowel cancer screeners, and not the endoscopist's specialty, determined adenoma detection rate [24]. Training and quality improvement would obviously have a role here and a group from the Mayo Clinic showed that an endoscopist quality improvement program resulted in an improved adenoma detection rate in those who were randomized to the training program compared to those who were not [25]. However, variable results have been reported by another systematic quality improvement program with five specific interventions designed to improve adenoma detection rate. In this study, no change in adenoma detection rate was noted over a 3-year period, despite these planned systematic interventions [26].

\section{Conclusions}

Efforts to improve adenoma detection rate in screening colonoscopy require colonoscopists to focus as much on technique as technology. High standards of colonoscopy can be achieved by adhering to simple technical standards. Remembering to spend time on withdrawal with adequate luminal distention and position changes to aid adenoma detection are important measures.

The other issues to focus on include considering the use of split dose bowel preparation to improve mucosal visualization and thereby adenoma detection rate. Considering the issue of operator fatigue and reducing the time spent in a stretch in the endoscopy unit in individual circumstances could have a benefit, but this could well be operator dependent. Not all colonoscopists may find trainees fun and stimulating, but their presence could lend an extra pair of eyes to improve adenoma detection rate. It is also worth considering video recording the entire procedure to heighten awareness among colonoscopists. Retroflexion and retroversion have not been shown to improve adenoma detection rate and this issue needs further study. The jury's still out on the role of hyoscine $\mathrm{N}$ butylbromide. Training and accreditation also probably play a role and emerging data seem to suggest that higher procedural volumes and quality improvement interventions could improve adenoma detection rate.

\section{Abbreviations}

ELS, electrolyte lavage solution; $\mathrm{NaP}$, sodium picosulphate; PEG, polyethylene glycol; RCT, randomized controlled trial.

\section{Disclosures}

The authors declare that they have no disclosures.

\section{References}

I. Hewitson P, Glasziou P, Watson E, Towler B, Irwig L: Cochrane systematic review of colorectal cancer screening using the fecal occult blood test (hemoccult): an update. Am J Gastroenterol 2008, 103:154|-9.

FlOOOPrime RECOMMENDED

2. Winawer SJ, Zauber AG, Ho MN, O'Brien MJ, Gottlieb LS, Sternberg SS, Waye JD, Schapiro M, Bond JH, Panish JF: Prevention of colorectal cancer by colonoscopic polypectomy. The National Polyp Study Workgroup. N Engl J Med I993, 329:1977-8I.

3. Baxter NN, Goldwasser MA, Paszat LF, Saskin R, Urbach DR, Rabeneck L: Association of colonoscopy and death from colorectal cancer. Ann Intern Med 2009, I50: I-8.

FlOOOPrime RECOMMENDED

4. Brenner H, Hoffmeister M, Arndt V, Stegmaier C, Altenhofen L, Haug U: Protection from right- and left-sided colorectal 
neoplasms after colonoscopy: population-based study. J Natl Cancer Inst 2010, 102:89-95.

5. Kaminski MF, Regula J, Kraszewska E, Polkowski M, Wojciechowska U, Didkowska J, Zwierko M, Rupinski M, Nowacki MP, Butruk E: Quality indicators for colonoscopy and the risk of interval cancer. N Engl J Med 2010, 362: I795-803.

\section{FlOOOPrime
RECOMMENDED}

6. Zauber AG, Winawer SJ, O'Brien MJ, Lansdorp-Vogelaar I, van Ballegooijen M, Hankey BF, Shi W, Bond JH, Schapiro M, Panish JF, Stewart ET, Waye JD: Colonoscopic polypectomy and longterm prevention of colorectal-cancer deaths. $N$ Engl J Med 2012, 366:687-96.

\section{FIOOOPrime} RECOMMENDED

7. Calderwood $\mathrm{AH}$, Jacobson $\mathrm{BC}$ : Comprehensive validation of the Boston Bowel Preparation Scale. Gastrointest Endosc 2010, 72:686-92.

\section{FlOOOPrime}

\section{RECOMMENDED}

8. Hillyer GC, Basch CH, Basch CE, Lebwohl B, Kastrinos F, Insel B], Neugut Al: Gastroenterologists' perceived barriers to optimal pre-colonoscopy bowel preparation: results of a national survey. J Cancer Educ 2012, 27:526-32.

\section{FlOOOPrime \\ RECOMMENDED}

9. Belsey J, Crosta C, Epstein O, Fischbach W, Layer P, Parente F, Halphen M: Meta-analysis: the relative efficacy of oral bowel preparations for colonoscopy 1985-20 I0. Aliment Pharmacol Ther 2012, 35:222-37.

\section{FlOOOPrime}

10. Enestvedt BK, Tofani C, Laine LA, Tierney A, Fennerty MB: 4-Liter split-dose polyethylene glycol is superior to other bowel preparations, based on systematic review and meta-analysis. Clin Gastroenterol Hepatol 2012, I0:|225-31.

\section{FlOOOPrime \\ RECOMMENDED}

II. Gurudu SR, Ramirez FC, Harrison ME, Leighton JA, Crowell MD: Increased adenoma detection rate with system-wide implementation of a split-dose preparation for colonoscopy. Gastrointest Endosc 2012, 76:603-8.el.

\section{FlOOPrime}

\section{RECOMMENDED}

12. Flemming JA, Vanner SJ, Hookey LC: Split-dose picosulfate, magnesium oxide, and citric acid solution markedly enhances colon cleansing before colonoscopy: a randomized, controlled trial. Gastrointest Endosc 2012, 75:537-44.

\section{FIOOPrime} RECOMMENDED

13. Seo EH, Kim TO, Park MJ, Joo HR, Heo NY, Park J, Park SH, Yang SY, Moon YS: Optimal preparation-to-colonoscopy interval in split-dose PEG bowel preparation determines satisfactory bowel preparation quality: an observational prospective study. Gastrointest Endosc 2012, 75:583-90.

\section{FlOOOPrime \\ RECOMMENDED}

14. Lurix E, Hernandez AV, Thoma M, Castro F: Adenoma detection rate is not influenced by full-day blocks, time, or modified queue position. Gastrointest Endosc 2012, 75:827-34

I5. Gurudu SR, Ratuapli SK, Leighton JA, Heigh RI, Crowell MD: Adenoma detection rate is not influenced by the timing of colonoscopy when performed in half-day blocks. Am Gastroenterol 201 I, I06:|466-7|.

FIOOOPrime

16. Lee A, Iskander JM, Gupta N, Borg BB, Zuckerman G, Banerjee B, Gyawali CP: Queue position in the endoscopic schedule impacts effectiveness of colonoscopy. Am J Gastroenterol 20 I I, I 06: | 457-65.

\section{FlOOOPrime} RECOMMENDED

17. Long MD, Martin C, Sandler RS, Herfarth HH, Shaheen NJ, Dellon ES: Reduced polyp detection as endoscopy shift progresses: experience with screening colonoscopy at a tertiary-care hospital. J Clin Gastroenterol 201 I, 45:253-8.

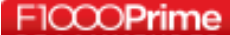

\section{RECOMMENDED}

18. East JE, Suzuki N, Arebi N, Bassett P, Saunders BP: Position changes improve visibility during colonoscope withdrawal: a randomized, blinded, crossover trial. Gastrointest Endosc 2007, 65:263-9.

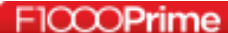

\section{RECOMMENDED}

19. East JE, Bassett P, Arebi N, Thomas-Gibson S, Guenther T, Saunders BP: Dynamic patient position changes during colonoscope withdrawal increase adenoma detection: a randomized, crossover trial. Gastrointest Endosc 201 I, 73:456-63.

\section{FlOOOPrime
RECOMMENDED}

20. Adler A, Wegscheider $K$, Lieberman $D$, Aminalai $A$, Aschenbeck J Drossel R, Mayr M, Mroß M, Scheel M, Schröder A, Gerber K, Stange G, Roll S, Gauger U, Wiedenmann B, Altenhofen L, Rosch T: Factors determining the quality of screening colonoscopy: a prospective study on adenoma detection rates, from I2, I34 examinations (Berlin colonoscopy project 3, BECOP-3). Gut 20I3, 62:236-4I.

2I. Lee RH, Tang RS, Muthusamy VR, Ho SB, Shah NK, Wetzel L, Bain AS, Mackintosh EE, Paek AM, Crissien AM, Saraf LJ, Kalmaz DM, Savides T]: Quality of colonoscopy withdrawal technique and variability in adenoma detection rates (with videos). Gastrointest Endosc 201 I, 74:128-34.

22. Gromski MA, Miller CA, Lee S, Park ES, Lee TH, Park S, Chung I, Kim S, Hwangbo Y: Trainees' adenoma detection rate is higher if $\geq 10$ minutes is spent on withdrawal during colonoscopy. Surg Endosc 2012, 26: 1337-42.

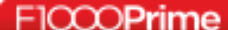

\section{RECOMMENDED}

23. Overholt BF, Brooks-Belli L, Grace M, Rankin K, Harrell R, Turyk M, Rosenberg FB, Barish RW, Gilinsky NH: Withdrawal times and associated factors in colonoscopy: a quality assurance multicenter assessment. J Clin Gastroenterol 2010, 44:e80-6.

\section{FlOOOPrime}

24. Buchner AM, Shahid MW, Heckman MG, Diehl NN, McNeil RB, Cleveland P, Gill KR, Schore A, Ghabril M, Raimondo M, Gross SA Wallace $M B$ : Trainee participation is associated with increased small adenoma detection. Gastrointest Endosc 201।, 73:1223-31.

\section{FlOOPrime}

\section{RECOMMENDED}

25. Eckardt AJ, Swales C, Bhattacharya K, Wassef WY, Leung K, Levey JM: Does trainee participation during colonoscopy affect adenoma detection rates? Dis Colon Rectum 2009, 52:1337-44.

26. Rex DK, Hewett DG, Raghavendra M, Chalasani N: The impact of videorecording on the quality of colonoscopy performance: a pilot study. Am J Gastroenterol 2010, 105:2312-7.

27. Madhoun MF, Tierney WM: The impact of video recording colonoscopy on adenoma detection rates. Gastrointest Endosc 2012, 75:127-33.

28. Saad A, Rex D: Routine rectal retroflexion during colonoscopy has a low yield for neoplasia. World J Gastroenterol 2008, I 4:6503-5. 
29. Rex DK: Accessing proximal aspects of folds and flexures during colonoscopy: impact of a pediatric colonoscope with a short bending section. Am J Gastroenterol 2003, 98: I504-7.

30. Harrison M, Singh N, Rex DK: Impact of proximal colon retroflexion on adenoma miss rates. Am J Gastroenterol 2004, 99:5 19-22.

31. Hewett DG, Rex DK: Inspection on instrument insertion during colonoscopy: a randomized controlled trial. Gastrointest Endosc 2012, 76:381-7.

32. Wildi SM, Schoepfer AM, Vavricka SR, Fruehauf H, Safroneeva E, Wiegand N, Bauerfeind $\mathrm{P}$, Fried $\mathrm{M}$ : Colorectal polypectomy during insertion and withdrawal or only during withdrawal? A randomized controlled trial. Endoscopy 2012, 44:1019-23.

33. Brouwer EJ de, Arbouw ME, van der Zwet WC, van Herwaarden MA, Ledeboer M, Jansman FG, ter Borg F: Hyoscine N-butylbromide does not improve polyp detection during colonoscopy: a double-blind, randomized, placebo-controlled, clinical trial. Gastrointest Endosc 2012, 75:835-40.

34. Corte C, Dahlenburg L, Selby W, Griffin S, Byrne C, Chua T, Kaffes A: Hyoscine butylbromide administered at the cecum increases polyp detection: a randomized double-blind placebocontrolled trial. Endoscopy 20I2, 44:917-22.

35. Cooper GS, Xu F, Barnholtz Sloan JS, Schluchter MD, Koroukian SM: Prevalence and predictors of interval colorectal cancers in medicare beneficiaries. Cancer 2012, I I 8:3044-52.
36. Baxter NN, Sutradhar R, Forbes SS, Paszat LF, Saskin R, Rabeneck L: Analysis of administrative data finds endoscopist quality measures associated with postcolonoscopy colorectal cancer. Gastroenterology 201 I, 140:65-72.

37. Singh H, Nugent Z, Demers AA, Bernstein CN: Rate and predictors of early/missed colorectal cancers after colonoscopy in Manitoba: a population-based study. Am J Gastroenterol 2010, 105:2588-96.

38. Bhangu A, Bowley DM, Horner R, Baranowski E, Raman S, Karandikar S: Volume and accreditation, but not specialty, affect quality standards in colonoscopy. Br J Surg 2012, 99:|436-44.

FlOOOPrime

39. Coe SG, Crook JE, Diehl NN, Wallace MB: An endoscopic quality improvement program improves detection of colorectal adenomas. Am J Gastroenterol 2013, I08:219-26 quiz 227.

FlOOOPrime

RECOMMENDED

40. Shaukat A, Oancea C, Bond JH, Church TR, Allen Jl: Variation in detection of adenomas and polyps by colonoscopy and change over time with a performance improvement program. Clin Gastroenterol Hepatol 2009, 7:1335-40. 